\title{
The Eastern Enlargement of the European Union: Public Discourses in the Czech and Slovak Republics
}

\section{Tereza Novotna}

\section{Introduction}

On 1 May 2004 ten countries of Central-Eastern and Southeastern Europe joined the European Union (EU) - eight post-communist states and two Mediterranean, among them the Czech and Slovak Republics. Nowadays it seems that the 'Eastern enlargement' of the EU was almost inevitable. If we consider only countries of the former Soviet bloc, the process of accession was marked by their effort to accept and implement a tremendous amount of European legislation and to execute other EU requirements, accompanied by domestic democratisation and economic transition. In this respect, both the Czech and Slovak Republics are typical cases. Their starting point, except for minor differences such as Slovakia's smaller size and larger economic burden compared to the Czech Republic, was the same. Therefore, the comparison of their advancement over ten years on the way to the EU can reveal the source of their final success and can serve as a guide for current candidate countries. How, then, can we measure and distinguish between their achievements? Both the Czech and Slovak Republics joined the EU at the same time, which means that they simultaneously managed to fulfil the necessary political, legal, and economic prerequisites demanded by the opposite side. In that sense, there is actually no difference between the two countries; we can say that when both states met the required criteria, it was clear that they were unquestionably going to become members of the EU.

To find a difference in their common success, we have to look elsewhere. The simplest possibility that offers itself is to examine separately their negotiation processes. From this point of view, there are several ways of assessing the accomplishments of the Czech Republic and Slovakia: comparing the amount of time needed for the successful completion of negotiations; comparing the speed (and thus the willingness and preparedness) of the respective governments to close individual negotiation chapters; or, if we would rather emphasize the ability to bargain exemptions as much as possible, comparing the number and significance of final transition periods. All of these options more or less depend on economic and legal reforms and on the implementation of the European acquis communautaire. An estimation of progress toward accession can be gauged from various reports of the EU bodies and concluding accession treaties. If all the laws and reforms are implemented, it is only a matter of time before both the Czech and Slovak Republics, and in general any candidate country, enters the EU.

This very mechanistic and thus very comfortable (especially for the politicians of candidate countries) attitude to the entire negotiation process neglects an essential part of accession: on one side, the political and civic readiness of candidate states to become members of the EU and, on the other side, their political and civic motivation. It will be argued that the chief obstacles on the 'way back to Europe' were not so much a formal and administrative acquis implementation, but internal political weakness and unsatisfactory public discourse on the merits of joining the EU. Slovakia, with its initial incorporation into the so-called second wave of candidate countries due to its domestic political situation, is the best illustration of the 
former obstacle, while the Czech Republic, with its relatively low level of 'yes-votes' in the closing referendum, is an exemplar for the latter.

The paper is divided as follows: the first two sections summarise the conditions for the previous and new enlargements and give a historical perspective on Czech-Slovak relations and the preliminary stage of negotiations including the Europe Agreements. The third section is devoted to the political development in Slovakia, the fourth section discusses the internal Czech political situation and development until 1999. The fifth section examines the final five years before the accession. The conclusion refers to referenda and evaluates the Czech and Slovak experience on the way to the European Union.

\section{Historical perspective I: the beginnings of the new enlargement}

Before its eastward expansion, the EU had already been enlarged several times. When in 1989 the Soviet bloc collapsed and former communist regimes in Central and Eastern Europe (CEE) embarked on the path to democracy and free market economies, it soon became apparent that for political, economic, and security reasons it was necessary for the European Communities to consider further enlargement to the East. The West European countries felt a 'collective responsibility' for their fellow Europeans who were oppressed for more than forty years and felt obligated to help them in their 'return to Europe' (Sedelmeier 2000). Moreover, it was a unique historical opportunity to extend the zone of security and peace and to foster stability across the European continent. In economic terms, the positive outlook promised the enlarged EU access to the biggest single market in the world. On the negative side of the balance sheet, there were concerns about the costs of the enlargement (particularly with respect to Common Agricultural Policy (CAP), structural funds, and labour migration) and about consequences for institutional functioning of the EU (Glenn 2003). The uncertainty about the costs and benefits was at the beginning of the 1990s even more pressing, since it was absolutely unclear if the hoped-for democratic and economic developments in CEE would in fact occur. On the other hand, the clause of Article 49 of the Maastricht Treaty stating that 'any European state which respects the principles in Article 6(1) [liberty, democracy, respect for human rights and fundamental freedoms, and the rule of law] may apply to become a member of the Union' (Glenn 2003: 214) became an evident stimulus in a decision that offered EU membership to post-communist countries. Eventually, some authors would consider this moral imperative a kind of 'rhetorical entrapment' (Moravcsik and Vachudova 2002; Schimmelfennig 2001) that did not allow EU member states to get out of their initial promises and forced them to continue on the initiated path to Eastern enlargement, whether they still wanted it or not.

Nevertheless, EU members were very cautious in their decision-making. Following a short delay of about four years, caused by the simultaneous internal reforms leading to the establishment of the European Union, it was agreed at the 1993 European Council summit in Copenhagen, that 'the associated countries in Central and Eastern Europe that so desire shall become members of the European Union.' From this time on, Eastern enlargement was really no longer a question of 'if,' but 'when.' Concerning the timing, the European Council states: 'Accession will take place as soon as an associated country is able to assume the obligations of membership by satisfying the economic and political conditions required.' At the same time, the summit defined three groups of membership criteria, which are known as the 'Copenhagen criteria':

1) democratic: stability of institutions guaranteeing democracy, the rule of law, human rights, and respect for and protection of minorities;

2) economic: the existence of a functioning market economy as well as the capacity to cope with competitive pressure and market forces within the European Union;

3) legislative: the ability to take on the obligations of membership including adherence to the aims of political, economic and monetary union.

Furthermore, in December 1995 the European Council summit in Madrid added the fourth condition: 
4) administrative: the creation of the conditions for candidate's integration through the adjustment of its administrative structures.

The rationale for the fourth additional criterion was the EU's concern that while the candidate countries may transpose the European legislation literally into national legislation, they may implement it ineffectively or through inappropriate administrative and judicial structures. The fear of European officials was quite understandable, since the bureaucracies of CEE had become notorious for their low respect for the rule of law, inclination to corruption and bribery, and unproductive working attitudes, all inheritances from the communist period.

In general, the Copenhagen Criteria put pressure on candidates' governments and limited their bargaining positions, since the criteria were understood as nonnegotiable prerequisites for any further discussion between candidate and member states. In the literature, the situation is referred to as the 'principle of conditionality' in which 'one partner has leverage over another through their ability to withhold a desired benefit, in this case, EU membership' (Glenn 2003: 216). The meeting of criteria thus became a condition sine qua non, which, in practice, resulted in changing domestic policies and institutions in order to bring them into line with EU requirements. The prospect of full membership tied to the necessity of conforming to EU standards definitely had a positive effect on reforms within the candidate countries and sped up democratisation and economic transformation (Mattli and Plümper 2004). In the later stages, however, this 'asymmetrical process in which the incumbent members, in the driving seat, engage with the candidates, which are supplicants and dependants' (Wallace 2000: 151) led to awkward consequences. The candidate governments (such as the left-centrist coalition in the Czech Republic since 1998) in a frenzied endeavour to endorse and implement as many of the 'European laws' as possible in the shortest time possible, somehow forgot to continue explaining to the public that EU membership was something more than new laws and regulations. Governments tended to shift the blame for accepting unpopular restrictive measures to the EU; though the measures would have to be approved anyway, they could easily be rationalised by the obligation to fulfil EU criteria. Moreover, from time to time, the governing parties managed to 'smuggle' some of their ideological proposals under European reasoning despite otherwise unbreakable parliamentary opposition. Nevertheless, let us go back first to the beginning of the century and to the situation in, at that time, Czechoslovakia.

\section{Historical perspectives II: the beginnings of the relationship between the Czech and Slovak Republics and the EU}

Czechoslovakia was established as an independent state in 1918 as a result of international treaties after World War I. During the period of the First Republic (1918-38), Czechoslovakia was a democratic state, even though it suffered from national rivalries between the Czech and Slovak majority on one side, and German and Hungarian minorities on the other. In the 1920s and 1930s, Czechoslovakia belonged to one of the most prosperous European regions. Following the Second World War, Germans were expelled from the Czech lands, while the Hungarian minority mostly remained (currently, about $11 \%$ of the Slovakian population is Magyar). After a short quasi-democratic period, Czechoslovakia fell under Soviet rule in 1948, the last country from Central Europe to do so. The rigid communist regime collapsed (again, the last one to do so) during the 'Velvet Revolution' in November 1989 and was followed by the dissolution of Czechoslovakia during the 'Velvet Divorce' in December 1992.

This brief historical overview brings us to the beginning of the 1990s and provides us with a sense of the prospects and hopes that Czechoslovakia (and later both successor republics) possessed and also evoked in other European countries. It was expected that the democratic and economic reforms would not encounter any serious obstructions. Czechoslovakia was perceived as one of the most progressive candidates. Therefore, in December 1989 a fouryear Agreement on Trade in Industrial Products was signed between the Czechoslovak and European Community (EC) representatives. This contract was replaced in May 1990 by the Agreement on Trade and Commercial and Economic Cooperation, valid for ten years, and by the Interim Agreement, which entered into force in March 1992. Both the Trade and Commercial 
and Interim Agreements established a free trade zone between Czechoslovakia and the EC and were supplemented in December 1991 by the so-called Association Agreement (The European Agreement on Association of the Czech and Slovak Federative Republic to the European Community). The conclusion of the Association Agreement was perceived as a great triumph, moreover, when Czechoslovakia was among the first countries to undersign it; it seemed to be explicit evidence of the primacy of Czechoslovakia within the group of candidate countries. In particular, the Minister of Finance and later Czech Prime Minister Václav Klaus spoke about the 'Central European tiger' and his rhetoric only reinforced the sense of Czechoslovak exceptionalism. Since the collapse of communism, Czechoslovak public discourse (and later Czech discourse) thus considered joining the EU as something unavoidable and logical, for it would really be absurd for EU members to reject such a studious and gifted pupil. Even though the imminent economic difficulties (which some predicted at the start of the decade and persist even now) cooled down the early Czechoslovak (or rather Czech) optimism, the self-evidence of the eventual accession was a sustained feature of the national discourse until its realisation. One of the harmful consequences that this excessive self-confidence bred was the scarce cooperation within the Central European region. Although in 1989 the Central European Initiative known as the Visegrad (or V3, later V4) group was established, comprising of Czechoslovakia (later Czech and Slovak Republics), Hungary, and Poland, and which envisaged the creation of a free trade area (Uvalic 2002), owing to the lack of interest, primarily on the Czech side, the initiative steadily died out until its mission shrank to symbolic political declarations and cultural matters. Therefore, the CEE countries did not form a firm block as the Scandinavian countries had done, which was certainly detrimental to their bargaining power.

Because of the division of Czechoslovakia, the Association Agreement could not be ratified and, therefore, could not enter into force. The EC recognised the necessity to conclude new agreements with both republics separately and did so during the Luxembourg European Council summit in October 1993. The so-called Europe Agreements (establishing an association between the European Communities and the Czech/Slovak Republic) have identical texts for the Czech and Slovak Republics and, due to a coincidence with the declaration of the Copenhagen criteria, are more constraining than the prior Association Agreement with Czechoslovakia (focusing predominantly on free trade and technical assistance but avoiding the political and legal requirements). Except for the abolition of trade customs and other restrictions pertaining to dumping prizes and monopolies, they established Association Councils which were to meet regularly and examine 'the application of this Agreement and the accomplishment of the Czech [Slovak] Republic's economic reforms' (Europe Agreement: Title II, General Principles, Article 7 (2)). The goal of the Agreements is to provide a framework for political dialogue, to promote the expansion of trade and harmonious economic relations, to provide financial and technical assistance to the respective Republics, and to promote cooperation in cultural matters. On the other hand, contrary to the prior 'Czechoslovak' Agreement, the new Europe Agreements offered an unambiguous perspective on EU membership (Sedelmeier 2000: 178), stating that their aim is 'to provide an appropriate framework for the Czech [Slovak] Republic's gradual integration into the Community' (Europe Agreement: Article 1(2)). Title V, Chapter III, Article 69 talks about the approximation of laws and the major precondition for both Republics to 'ensure that [their] legislation will be gradually made compatible with that of the Community.' A year later, in 1994, the European Council in Essen set up the so-called pre-Accession strategy that was designed to improve preparation of candidate countries for EU membership. The strategy was based on the application of the Europe Agreements through the Association Councils, on financial support through the EU Phare Programme, and on a 'structured dialogue' that was supposed to unite all member and candidate states in solving questions of a common interest. Even though the Association Councils were the key bodies serving to aid candidate countries in their pre-accession efforts, they have also been denounced as 'institutional satellites' of the EU. The criticism was mainly aimed at the fact that the EU continued to develop new regulatory policies, which then had to be transposed into candidates' legislations, while simultaneously negotiating with the applicant countries and binding them with the prior agreements. The EU thus unilaterally defined and constantly modified the body of rules, which candidates had to accept (De Witte 2002: 237). Nevertheless, this situation was not entirely new, since this had happened during previous enlargements, albeit not to the extent witnessed at this time. 


\section{The political perspective: internal development in the Czech and Slovak Republics in 1990s}

Following the split of Czechoslovakia, a shift in public discourse occurred and the Czech Republic became the prime heir of the former Czechoslovak enthusiastic spirit. The Czech Republic underwent a fairly successful economic transformation (although there remained large state-owned banks and industry companies to be privatised and problems with the 'tunnelling'); the internal political situation was stable. Statistical data (World Bank 2002) from the first half of the 1990s seem to justify the self-confidence of the Czech people as well as the politicians: the private sector grew to $65 \%$ of GDP in 1994 (the best result of all candidate countries), foreign direct investment amounted to 2.9\% of GDP in 1995 (the third best result after Hungary and Estonia), and the Czech Republic scored almost 0.85 on the liberalization index (ranging from 0 to 1) of the World Bank in 1995 (the best result, tied with Hungary). The Slovak outcomes were much less impressive, though still better than most other countries. To do justice, we must admit that the Slovak economy inherited a more damaging legacy from the communist times: a greater share of polluting factories, the military and other heavy industries, and a less skilled labour force (Tétreault, Teske 1997). Nonetheless, the Slovak 'lagging behind' was not so serious that Slovakia could not catch up and even surpass its 'older brother.' In principle, what both countries show is that the economic transition was accomplished several years before the actual enlargement and hence disprove the fears that the accession of CEE countries would bear extreme costs for member states. In the words of game theory, the enlargement was eventually a 'win-win' situation where both sides gain (Hall, Quaisse 2001).

However severe the economic situation might have been, it was not a primary concern to the Slovak public, particularly in the immediate aftermath of independence. What mattered most was the regained national sovereignty - the 'regained' original sovereignty being that from the period during World War II when Slovaks had their own state (though strongly authoritative, even fascist) or that of the Moravian Empire about a thousand years ago (an opinion often subject to ridicule) - and the possibility to finally realise fully the Slovak 'right of self-determination.' In this period of heightened nationalism, the endeavours to become a member of a supranational collective such as the EU had to play second fiddle. If Slovak politicians mentioned the accession, they talked about their pleasure when Slovakia would have its own 'star' on the European flag; nonsense in itself. The Slovak public, therefore, perceived any issue pertaining to joining the EU (and NATO) as secondary and of minor importance, especially since the shade of the former Czechoslovak feeling of its unavoidability covertly endured in Slovakia as well. The national leader who (together with V. Klaus) 'divorced' Czechoslovakia and brought the Slovak Republic to existence (and who, therefore, enjoyed immense public popularity) was Vladimir Meciar, the Prime Minister and head of the Movement for Democratic Slovakia - Hnutie za demokratické Slovensko (HZDS). His party has been successful in all the parliamentary elections ${ }^{1}$ since independence and became a driving force in the Slovak 'national way' to democracy and prosperity. The 'reign' of V. Meciar (1993-98) is, however, ambiguous; it is usually ranked somewhere between a kind of populism and semi-authoritarianism. In foreign affairs, Meciar's government maintained EU and NATO accession as a state priority; ${ }^{2}$ nevertheless, it has been accused of an Eastwardlooking orientation in policy, particularly in regard to foreign trade (Nello 2002: 296). Eventually, on 27 June 1995 Prime Minister V. Meciar submitted the application of the Slovak Republic for EU membership at the European Council summit in Cannes, while Czech Prime Minister V. Klaus applied for EU membership six months later, on 23 January 1996 at the summit in Rome. Despite Slovak official declarations and foreign policy steps, the most striking problem became the deteriorating domestic political situation. The dissatisfaction with Slovak progress was reflected in several EU documents: the EU-demarches from December 1994 and November 1995, the Presidency declaration from March 1998, and, most importantly, the Resolution on the Need to Respect Human and Democratic Rights in the Slovak Republic adopted by the European Parliament on 16 November 1995 (and repeated in December 1996). After enumerating grievances against the Slovak Republic (e.g. attempts to deprive democratically elected representatives from opposition parties of their seats in parliament, political intrusion into police investigation and media), the November EP Resolution (4) concludes: 'The European Parliament points out to the Government of the 
Slovak Republic that, if it continues to follow policies which show insufficient respect for democracy, human and minority rights and the rule of law, it will be necessary for the European Union to reconsider its programmes of assistance and cooperation under the Europe Agreement which might have to be suspended.' This was not just an admonition of an immature youngster, but a sign of an understandable anger threatening practical consequences in the foreseeable future. Unfortunately, Meciar's government found demarches and resolutions as nothing more than EU interference in Slovak internal matters, ${ }^{3}$ while the opposition and President warned of the Slovak Republic's pending isolation (Slivkova 1999: 8).

On 16 July 1997 the European Commission published the strategic document Agenda 2000: For a Stronger and a Wider Union. In its introduction, the Commission announced that at the request of the Council, the Commission worked up Opinions on Applications for Membership of ten candidate countries. In its opinion, the Commission took into account answers to the Commission's questionnaires submitted by the candidate countries a year ago, evaluations on progress toward realization of Copenhagen requirements, and reports and resolutions of the European Parliament and other governmental and non-governmental institutions. It came as no surprise that the Commission maintained that, even though a number of countries needed to move forward in the practical application of democracy and protection of minorities, there was only a single candidate state - Slovakia - that did not meet the political criteria adopted by the Copenhagen Council summit. In the detailed Opinion on Slovakia's Application for Membership of the European Union, C. Summary and Conclusion, the Commission explained that 'government does not sufficiently respect the powers devolved by the constitution to other bodies and that it too often disregards the rights of opposition... the use made by the government of the police and the secret services is worrying... Despite recommendations made by the European Union in a number of demarches and declarations, there has been no noticeable improvement.' The opinion concluded, 'Slovakia does not fulfil in a satisfying manner the political conditions... because of the instability of Slovakia's institutions, their lack of rootedness in political life and the shortcomings in the functioning of its democracy. This situation is so much regrettable since Slovakia could satisfy the economic criteria in the medium term and is firmly committed to take on the acquis.' For a comparison, let us quote from an analogous Opinion on the Czech Republic's Application for Membership: 'The Czech Republic's political institutions function properly and in conditions of stability... There are no major problems over respect for fundamental rights... the Czech Republic can be regarded as a functioning market economy... further administrative reforms will be indispensable if the Czech Republic is to have the structures to apply and enforce the acquis fully.' As a final proposal, the Commission suggested that Hungary, Poland, Estonia, the Czech Republic, and Slovenia could in a mid-term perspective meet all the criteria for membership, and accession negotiations should be opened with them. The European Council at the summit in Luxembourg in December 1997 followed the Commission's recommendation and initiated negotiations with five candidates; Slovakia was excluded from this 'first wave' and incorporated into the 'second wave.' As E. Slivkova noted, 'Slovakia missed the most suitable moment for starting negotiations' (Slivkova 1999: 13).

\section{On the way to the European Union: the true prospect of the enlargement}

On 31 March 1998 the EU opened accession negotiations with six 'first wave' countries (Cyprus was added) and the preliminary period of the 'screening' (i.e. comparing the candidate's legislation with that of the EU), divided into 31 so-called chapters, was launched. After each chapter's legislation is 'screened,' a candidate country prepares its position document determining when it will transpose the given part of acquis. The position document is handed over to the Commission which then outlines the common position of the member countries. If the Council approves the common position, the negotiation process begins. In contrast to previous enlargements, however, the renewed 'classical community method' did not allow for permanent opt-outs (e.g. from the Monetary Union); applicants were expected to accept the obligations of membership in full (Glenn 2003). The only exception they could achieve were 'transition periods' enabling postponement of the deadline for full acquis implementation by several years. In special cases, 'permanent 
exceptions' were also admitted. This situation generated even more pressure for the candidate countries, since they could be sure that, in any case, the complex body of regulations would be implemented sooner or later. In the Czech Republic, for example, the necessity to approve 'European laws' accelerated the 'state of legislative emergency' that reduced the Czech legislative process: specific bills could be passed in one reading with no amending proposals unless two parliamentary factions or 50 deputies protest against them. Although this stipulation assured that any governing coalition did not produce excessively ideological proposals under the 'European label,' to some extent it was a limitation of the legislative branch and outweighed the balance of power on the executive side paradoxically, the democratic feature that was so valuable to European partners.

The Czech Republic, meanwhile, experienced several substantial changes: an economic downturn and corruption affairs that led to the collapse of the right-wing cabinet of V. Klaus, subsequent exceptional elections, and an advance of the opposing social democrats to power. ${ }^{4}$ A major shift in the 'European' public discourse followed one such scandal in V. Klaus' Civic Democrats - Občanská demokratická strana (ODS). Once the political party that enthusiastically presided over the transformation and applied for EU membership, the ODS was becoming more and more pessimistic about the Republic's prospects (blaming the governing social democrats) and more and more euroskeptical (resembling, some times rather tragicomically, British conservatives). The new atmosphere within the party can be illustrated in a few quotations from the 'Czech Eurorealist Manifesto,' politically engaged intellectuals, one of whom is now a Member of the European Parliament (MEP). Although the Manifesto sets out two strategic priorities - integration into the EU and NATO - it sees EU membership as the 'most extensive modern voluntary hand-over of part of our sovereignty to a 'supranational' level,' and the Economic and Monetary Union as primarily a political project (which has to be, therefore, preceded by a referendum); the negotiation process is seen as a skilful tactic which transformed the EU's enlargement into a competition by which the EU manages to rearrange the candidate queue according to its opportune needs; and the requirement to implement the entire acquis is an 'anti-dumping measure that quickly liquidates even the rest of the comparative advantages that the Central-Eastern European economies so far possessed' and which 'is not so much about meeting declared 'high' standards, but is mainly a protectionist weapon defending the European market before the external competition.' Before serving his term in the 'underdeveloped' European Parliament, the MEP author of the Manifesto issued a proclamation announcing, 'because of the non-existence of the 'European' public and 'European' voters, the European Parliament can never become a developed parliament.' As a consequence of all these assumptions, the Manifesto insists that the Czech Republic has two vital interests: participation in EU decisionmaking processes and involvement in the single market, not as an inferior and secondary, but full-fledged member. At the same time, the Czech Republic should be attached to the intergovernmental model that is not 'projected from desks of European political and bureaucratic elites' and in which, by keeping the right of veto, national identity 'is not reduced to a sort of negligible cultural-folklore element.' If the Czech Republic does not reach these prerequisites for its entry, the Manifesto offers two viable alternatives, either a bilateral solution 'based on the Swiss model' or closer economic ties with the United States and the North American continent, for 'in the globalized trade exchange, geographical distance loses its significance' (joining the US as a Central European fifty-first state was not suggested). This lengthy citation from one party's programmatic paper expresses the mood that tended to rule over about half of Czech society. The discourse between politicians and the public was a puzzling mixture of the continuing exceptionalism with unfounded fears and doubts about the 'European socialist superstate,' mix of a theoretical knowledge with demagogy and populism. In addition the euro-optimists seasoned increasingly nationalistic discussions with glorifications of the EU and immoderate expectations from its membership. Besides this, the former front-runner had difficulties keeping up with other 'first wavers' and this necessarily affected the overall atmosphere in Czech society and its relationship with the outside world, particularly the EU.

On the other side of the Czech-Slovak border, the situation started to look much rosier. Although the EU demarches did not have a desirable outcome, the incorporation of Slovakia among the 'second wave' candidates certainly produced a wake-up call. The Slovak 
disappointment was accentuated by the decision on the first NATO enlargement, again with a Slovak absence. The public began to realise that with such a domestic policy it could really soon belong to the 'Wild East.' The intensifying excesses of Meciar's government (e.g. with respect to the Hungarian and Roma population or electoral rule, see Toma and Kovac 2001, Goldman 1999) led to reverse consequences - an amounting unified resistance. Before the elections in 1998, the fragmented opposition integrated itself into one party block and, with a remarkable $84 \%$ turnout, removed V. Meciar and his coalition from power. The new cabinet's leader and head of the second strongest party, Mikuláš Dzurinda, went on his first official visit to Brussels and embarked on the path to democracy stabilisation, protection of national minorities (e.g. by a new minority language law adopted in July 1999), and economic recovery. The European Union showed its appreciation for the Slovak progress repeatedly in 1999 and 2000: 'Slovakia continues to meet the political criteria for accession which the last report had recognized, for the first time, as having been fulfilled. Slovakia has further advanced in the consolidation of its democratic system and in the normal functioning of its institutions' (2002 Regular Report on Slovakia's Progress Towards the Accession, November 2002). Slovakia also improved its economic shape. The successful development was completed in December 1999 when at the Helsinki European Council summit the EU member states accepted Slovakia as a candidate for EU membership and on February 15 th 2000 the official negotiations on the Slovak accession began in Brussels. Even though (or perhaps because) Slovakia was two years behind, it became one of the most industrious and wholehearted newcomers. The passionate atmosphere of the early nineties switched in the two parts of former Czechoslovakia.

\section{5. 'Konec dobrý, všechno dobré' ('All's good that ends well’)}

According to L. Friis and A. Murphy (2000), the 1999 Helsinki summit, which in fact merged the first and second waves into one, was a rational solution to the 'complex juggling act' of how to crack such intricate problems as the issue of Czech and Slovak borders and custom union that both countries shared. If one of those states would have become an EU member and the other did not, the customs union would have to have been abolished. From this point of view, the decision to open the negotiations was a result of EU officials' rational problemsolving rather than evidence of Slovakia's progress. Along these lines, the 'regatta' or 'Big Bang' option (as opposed to 'minimal' or 'two waves' enlargement) was also an answer to the frightening 'queue-management' (Friis, Murphy 2000). After Helsinki, everything went along smoothly. Both countries focused on chapter negotiations: the Czech Republic had the advantage of an earlier start and thus was able to conclude one-third of the chapters by the end of 1999. The Slovak Republic was offered a 'package deal' to begin with and concluded negotiations of one third of the chapters in eight months by October 2000 (which is another sign of Slovak renewed eagerness, but also of a lesser bargaining competency). For the final round, chapter No.7, Agriculture, and No.29, Finance and Budgetary Provisions, were to be concluded for all the candidate countries, while the Czech Republic also had to conclude chapters No.9, Transport Policy, and No.30, Institutions. In 1997 at the Amsterdam summit (before the negotiations started), it had been recognised that the Eastern enlargement required the EU to undergo substantial internal reforms. The Amsterdam Treaty nonetheless did not unravel the tricky institutional arrangements and Amsterdam's 'left-overs' remained for the European Council summit in Nice to answer in December 2000. The adopted Treaty of Nice, among others, established changes in weighting votes in the EU Council and in the number of seats in the European Parliament after the EU enlargement. While the Czech Republic with its 10.3 million inhabitants received 12 votes in the Council (similar to equally populated Belgium, Greece, Portugal, and Hungary), it was, along with Hungary, awarded only 20 seats in the European Parliament (whereas Belgium, Greece, and Portugal obtained 22 seats). Although the discrepancy of two seats in a 732-member Parliament makes a rather minimal difference, it was a blow to national pride of the Czech Republic (and even more so to Hungary) and made the Czech and Hungarian diplomats unwilling to concede at any price to the Institutions chapter. In the Czech Republic, moreover, this unfortunate EU decision gave euro-realists evident proof of the future 'dictate of power' in the EU that would happen if smaller states agreed with a federalist Europe. On the other hand, the rhetoric of opposition did not influence public discourse very much at this point for a simple reason - the Czech 
public either did not understand or did not care about what 'those at the top' were actually doing during the summits. The impact was, therefore, mild and only reinforced the growing scepticism toward EU membership.

On 12-13 December 2002 at the European Council summit in (symbolically) Copenhagen, ten candidate countries officially finished accession negotiations and the European Council decided on the accession of the Czech and Slovak Republics. The final Treaty of Accession, whose ceremonial signature took place in Athens on 16 April 2003, was designed as one treaty between all ten new states and fifteen member states. The Accession Treaty contains three main parts - the relatively short proper text of the treaty, the Act of Accession, and the Final Act. The main body of the 5,000 page long document contains the Accession Act with annexes and protocols. The Act of Accession, Part I, Article 3 is devoted to the so-called Schengen acquis and refers to Annex I, which divides the Schengen provisions into two categories: the category I regulations, which became valid immediately after the Treaty entered into force, and the category II regulations, which will be binding after the Council decides on their obligatory force, i.e. after new member states demonstrate their capability to enforce the regulations. Such complicated provisions ensure that new members will be able to protect the EU's so-called external borders. In the case of the Czech Republic the Schengen acquis is far less problematic, since, due to its geographical location, the single external border is Prague international airport; Slovakia is in a more delicate ${ }^{6}$ position because of its external borders with Ukraine. In principle, the new member states should accede to the Schengen acquis in full by 2008. A similar temporary exception establishes Article 4, which presupposes that the new member states will join the Economic and Monetary Union (EMU) after they meet the Convergence Criteria. Both the Czech and Slovak Republics are so far not in shape economically to fulfil the criteria (particularly because the Czech budget deficit continuously exceeds the required 3\% limit), and the earliest date possible for their integration into the eurozone is expected to be around the year 2010. Part II: Adjustments to the Treaties introduces the institutional modifications settled at the Copenhagen summit. The EU tacitly acknowledged its mistake and accorded the Czech Republic and Hungary with an additional two seats in the EP. Part IV: Temporary Provisions refers to temporary derogations from the Accession Treaty (i.e. transition periods and permanent exceptions) and to Annexes and Protocols of the Act that provides their details. The most challenging issues dealt with during the Copenhagen summit were the transition periods (demanded both by the candidate states and the EU) and the question of what to do with the financial contributions from the Common Agricultural Policy and structural funds. The agricultural matters were more disturbing for Slovakia than for the Czech Republic, given the higher percentage of the populace employed in the agricultural sector (Slovakia - 6.6\%, the Czech Republic - 4.9\%), the higher share of agriculture on GDP (Slovakia - 4.5\%, the Czech Republic - 3.9\%), and more serious environmental implications, e.g. biodiversity affected due to abandonment of land (European Environmental Agency 2004). Notwithstanding the minor differences between both states, the overall CAP reform and financial package should not have a diverse effect on either country.

The transition periods enjoyed much more attention in Czech and Slovak media and public discourse. The main concern troubling both societies was the 'buying out of our family silver' or the acquisition of agricultural land and forests and real estates by foreigners. The fears that Sudeten Germans, expelled after the WWII, would flood border regions or that Magyar families would immediately buy weekend houses in the Slovak countryside were, indeed, groundless (even though foreign-based companies had been allowed to buy Czech and Slovak property for years if they were registered in the respective country), but nonetheless were intense concerns. The EU eventually agreed to a seven-year transition period (i.e. purchase prohibition) for land and forests and five-year period for real estate in exchange for a seven-year transition period that restricts the free movement of labour for newcomers, which was no less popular and, presumably, no less unreasonable request from the European public. Nevertheless, the EU members allowed negotiating on a bilateral basis; now Czech and Slovak workers can be employed in the United Kingdom, Ireland, Netherlands, Sweden, and Denmark. The temporary limitation of the free movement of persons was demanded particularly by two neighbouring countries - Germany and Austria, which were expected to bear the largest migration costs (annual estimate was 300,000 migrants, of which 200,000 
were going to Germany) (Hall, Quaisse 2001, Schimmelfennig, Sedelmeier 2002). ${ }^{7}$ A similar concern pertaining to haulage created a transportation transition period of five years. In both the Czech and Slovak Republics, the public applauded the preservation of the lower valueadded tax to cigarettes and tobacco products; and Slovaks were happy, since their team negotiated exemption until 2008, while the Czech one until 2007. Equally applauded was the permanent exception to distil special national fruit liquors, which are considered parts of national identity (slivovice in Slovakia and jablečná pálenka i.e. calvados in the Czech Republic). The remaining transition periods were rather of an expert nature (e.g. waste management or harmonisation of hygienic standards) and therefore, did not evoke major public concern. In comparison, the Czech Republic negotiated a smaller number of transition periods (though the difference is minor), which can mean either that Czech diplomats were less skilful negotiators, or, more likely, that the Czech Republic was simply able to conform to the EU standards a bit more easily.

\section{Conclusion}

Since the integration of new members is subject to the assent procedure, the European Parliament cast the required majority of votes on the enlargement on April $9^{\text {th }}, 2003$. Another precondition was the ratification of the Treaty of Accession by April $30^{\text {th }} 2004$. Before it could happen, all the candidate countries (except Cyprus) chose to hold membership referenda. Owing to the improved communication among V4 group members, ${ }^{8} \mathrm{~V} 4$ countries approved a 'domino effect' order of referenda, so that the first to vote were those with the greatest support for EU membership. If we look at the Eurobarometer results from Spring 2003 and Autumn 2004, the situation was worrying. Both the Czech Republic and Slovakia showed declining support for their membership, though Slovak support was considerably higher (or at least closer to $50 \%$ ) than the Czech support (see figure 1).

How come the Czech Republic, the country that has always been reckoned to be the leading candidate state, is less in favour than other countries? Why is Slovakia, which managed to do well enough to get out of its political curse, not as eager as it was before? The Slovak case is easier to explain: even though Slovakia was fighting for its membership since 1998, any passion lasts shortly and, with time, cools down. Moreover, HZDS and its leader V. Meciar did not discredit itself, but further operated on the Slovak political scene, saying that 'the national interest of the Slovak Republic is to guarantee its sovereignty, territorial integrity, inviolableness of borders, security, and economic prosperity. To do so, we had to achieve a full-fledged membership in the EU and NATO's. How similar those words are to the statements from the Eurorealist Manifesto, co-authored by the former Deputy President of ODS, current MEP, and a 'shadow minister of foreign affairs.'10 As G. Delsoldato put it: 'Populist national parties basing their political message on the defence of the predominant national identity tend to be critical of the modalities of EU accession though supporting it in principle' (Delsoldato 2002: 283). Today, the position of ODS is that the accession of the Czech Republic to the EU was 'our strategic goal for economic and political reasons,' but any further development toward federalisation 'would lead to the significant reduction, or even elimination, of the state sovereignty... and, therefore, is in contradiction with our national interests, and, being so, is for us unacceptable (Zahradil 2004). ${ }^{11}$ An identical (or even more euro-skeptical) agitation also led the new President of the Czech Republic, V. Klaus who, since his election in 2003, has enjoyed popularity in public polls. It is no wonder that in such an atmosphere and state of the public discourse, only $77.3 \%$ of votes were in favour of the membership, which is relatively little in contrast to $92.46 \%$ positive votes in Slovakia. ${ }^{12}$

The experience of both republics is telling: even if the economic integration is successful and the European legislation is more or less implemented, what in the end matters is a political readiness to enter the $\mathrm{EU}$ and the motivation of the public to become its member. First of all, the understanding that the political criterion is not only a plain phrase but a firm precondition for EU membership might be a warning to the current candidates as well. Secondly, although it is important how many chapters are concluded, what kind of transition periods negotiated, and how much money countries get and pay, the self-evidence of the accession can change overnight if public discourse is led by leaders who, rather than realistically explaining the pros 
and cons of the membership, are playing on the nationalist and populist note. In any case, the Treaty of Accession entered into force on 1 May 2004 and the Czech and Slovak Republics joined the European Union, which shows that, despite all the obstacles and difficulties, the 'inevitable' can eventually materialise.

\section{Annex}

Figure 1: Eurobarometer Results, Spring 2003 and Autumn 2004

Generally speaking, do you think that your country's EU membership is...?

$\square$ A good thing $\square$ A bad thing $\square$ Neither good or bad

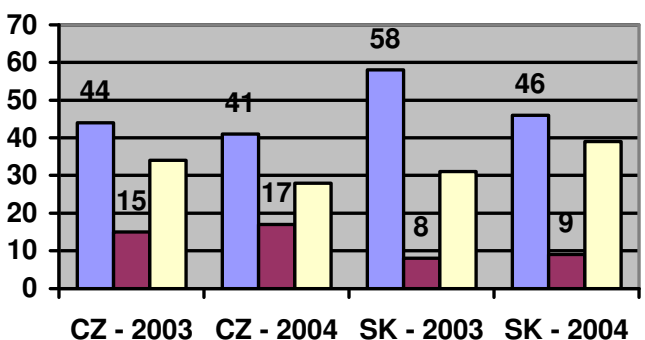

Taking everything into consideration, will your country get advantages from EU membership?

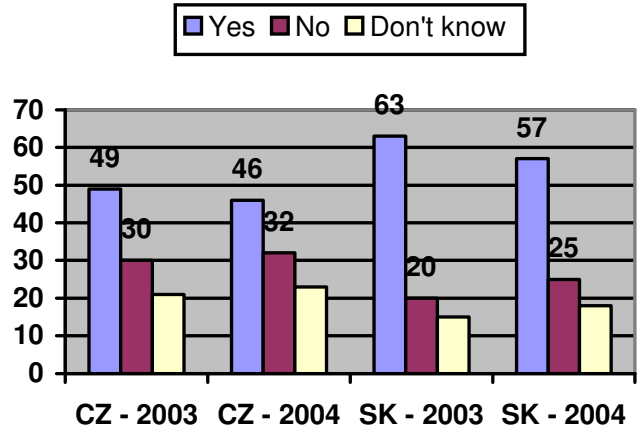

\section{Notes}

${ }^{1}$ In 1994 HZDS received almost 35\%, in 1998 27\%, and in $200219.5 \%$ of votes.

2 For example, in the inaugural speech in $1995 \mathrm{~V}$. Meciar declared: 'In the sphere of international policy the government of the Slovak Republic will unambiguously keep the continuity of its orientation. We want to carry on in the hitherto existing policy of integrating Slovakia into European and Trans-Atlantic political, security, and economic structures.'

${ }^{3}$ A press spokesman for HZDS even reacted by saying: 'Concerning the European Parliament resolution to Slovakia, HZDS reminds you of a recent story, when the leaders of Nazi Germany first sent countries demarches, and then occupied them with tanks.' Not surprisingly, HZDS representatives distanced themselves from the spokesman's remarks, calling them his own personal opinions and not the official HZDS party standpoint.

${ }^{4}$ One from the Czech peculiarities was 'The Pact on the Creation of the Stable Political Environment,' or the 'opposition agreement,' between the minority social democratic government and V. Klaus' opposition 'civic' party (besides these, there were three other smaller parties in the parliament). Based on the agreement, the minority cabinet was tolerated by the ODS in exchange for several concessions (e.g. proposed changes of the electoral rule) and offices. Basically, the agreement was targeted against smaller parties and was a hidden major coalition with a vague distribution of responsibilities between government and opposition.

${ }^{5}$ The document can be found at the Civic Democratic Party (ODS) web page, at http://www.ods.cz/knihovna/dokument.php?ID=11 as of December 15, 2004

${ }^{6}$ The Slovak-Ukraine border is also considered one of the main points for the trafficking of goods and people into the EU. See 'Slovak police fight losing battle on eastern front,' Financial Times, December $9^{\text {th }}, 2004$, p.4.

${ }^{7}$ So far it seems that even these estimates were exaggerated. Moreover, as in the case of the Czech Republic, the mutual quotas for employment that already now exist are far from their fulfillment.

${ }^{8}$ Communication improved due to the governmental change in the Czech Republic in 1998 and a common Czech-Hungarian strategy since 2000.

${ }^{9}$ See official web page of the HZDS, www.hzds.sk. 
${ }^{10}$ The similarity between HZDS and ODS is obvious also in other points: both parties are the strongest political parties, both are currently in the opposition, V.Meciar and V.Klaus also share a similar political past and other characteristics (nevertheless, the new ODS leadership attempts to distance itself from V.Klaus, not only because the presidential function in the Czech Republic is considered 'impartial').

$11 \mathrm{~J}$. Zahradil further stresses that ODS is against multi-speed Europe and the Constitutional Treaty.

12 The referendum in Slovakia took place on May 16-1 $7^{\text {th }}, 2003$, whereas in the Czech Republic on June 15-16 ${ }^{\text {th }}, 2003$ (V4 group: Hungary, Slovakia, Poland, Czech Republic). The turnout in Slovakia was $52.15 \%$ (i.e. only $2.15 \%$ above the required $50 \%$ level), in the Czech Republic $55.21 \%$ (50\% participation not binding).

\section{References}

Adrián, Petr, Bednář Miloslav, Plecitý, Petr and Zahradil, Jan (2001). Czech Eurorealist Manifesto: The Document for the Ideological Conference of ODS (Manifest českého eurorealismu: document $k$ ideové konferenci ODS), http://www.ods.cz/knihovna/dokument.php?ID=11

Goldman, Minton F. (1999). Slovakia since Independence: A Struggle for Democracy. Westport, London: Praeger.

Toma, Peter A. and Kováč, Dušan (2001). Slovakia: From Samo to Dzurinda. Stanford: Hoover Institution Press.

Muravcsik, Andrew and Vachudova, Milada A (2002). 'National Interests, State Power, and EU Enlargement', Center for European Studies, Working Paper No.97.

De Witte, Bruno (2002). 'Anticipating the Institutional Consequences of Expanded Membership of the European Union', International Political Science Review, 23 (3), pp. 235-248.

Delsoldato, Giorgia (2002). 'Eastward Enlargement by the European Union and Transnational Parties', International Political Science Review, 23 (3), pp. 269-89.

Eurobarometer, (2004).

http://europa.eu.int/comm/public_opinion/archives/cceb/2004/cceb_2004.1 first anx.pdf

Europe Agreement establishing an association between the European Communities and the Czech/Slovak Republic, http://www.euroskop.cz/cze/article.asp?lng=cz\&id=42465

The European Agreement on Association of the Czech and Slovak Federative Republic to the European Community,

http://www.euroskop.cz/cze/article.asp?id=42465\&chapter=3\&preview=\&cat=\&ts=10ec46

European Commission (1997a). Agenda 2000: For a Stronger and a Wider Union (Brussels: European Commission),

http://www.rcie.lodz.pl/dokumenty/pdf/agenda2000 for a stronger and wider union.pdf

European Commission (1997b). Opinion on the Czech Republic's Application for Membership, (Brussels: European Commission),

http://ec.europa.eu/enlargement/archives/pdf/dwn/opinions/czech/cz-op en.pdf

European Commission (1997c). Opinion on Slovakia's Application for Membership, (Brussels:

European Commission),

http://ec.europa.eu/enlargement/archives/pdf/dwn/opinions/slovakia/sk-op en.pdf

European Commission (2002). 2002 Regular Report on Slovakia's Progress Towards the Accession

(Brussels: European Commission) 
European Environmental Agency (2004). Environmental Issue Report No. 37: Agriculture and the Environment in the EU Accession Countries. Copenhagen: EEA.

European Parliament (1995). Resolution on the Need to Respect Human and Democratic Rights in the Slovak Republic, (Strasbourg: European Parliament)

http://www3.europarl.eu.int/omk/omnsapir.so/pv2?PRG=CALDOC\&FILE=951116\&LANGUE=E N\&TPV=DEF\&LASTCHAP=24\&SDOCTA=9\&TXTLST=3\&Type $D o c=R E S O L \& P O S=1$

Friis, Lykke and Murphy, Anna (2000). 'Enlargement: A Complex Juggling Act', in Cowles, Maria Green and Smith, Michael (eds.), The State of the European Union, Vol.5: Risks, Reform, Resistance, and Revival. Oxford: Oxford University Press, pp. 186-206.

Glenn, John K. (2003). 'EU Enlargement', in Cini, Michelle (ed.) European Union Politics. Oxford: Oxford University Press. pp. 211-228.

Hall, John and Quaisse, Wolfgang (2001). 'Europe's Eastern Enlargement: Who Benefits?', Contemporary History, 100 (649), pp. 389-393.

Mattli, Walter and Plümper, Thomas (2004). 'The Internal Value of External Options: How the EU Shapes the Scope of Regulatory Reforms in Transition Countries', European Union Politics, 5 (3), pp. 307-330.

Nello, Susan Senior (2002). 'Preparing for Enlargement in the European Union: The Tensions between Economic and Political Integration', International Political Science Review, 23 (3), 291 317.

Schimmelfennig, Frank and Sedelmeier, Ulrich (2002). 'Theorizing EU Enlargement: Research Focus, Hypotheses, and the State of Research', Journal of European Public Policy, Special Issue, 9 (4), pp. 1-26.

Sedelmeier, Ulrich (2000). 'Eastern Enlargement: Risk, Rationality, and Role-Compliance', in Cowles, Maria Green and Smith, Michael (eds), The State of the European Union, Vol.5: Risks, Reform, Resistance, and Revival. Oxford: Oxford University Press, pp. 164-185.

Slivkova, Eva (1999). Slovakia's Response on the Regular Report from the European Commission on Progress toward Accession, Center for European Integration Studies, Rheinische FriedrichWilhelms-Universität Bonn, Discussion Paper 57.

Tétreault, Mary A. and Teske, Robin L. (1997). 'The Struggle to Democratize the Slovak Republic', Contemporary History, 96, (608), pp. 135-139.

Uvalic, Milica (2002). 'Regional Cooperation and the Enlargement of the European Union: Lessons Learned?', International Political Science Review, 23 (3), pp. 319-333.

Wallace, Helene (2000). 'EU Enlargement: A Neglected Subject', in Cowles, Maria Green and Smith, Michael (eds), The State of the European Union, Vol.5: Risks, Reform, Resistance, and Revival. Oxford: Oxford University Press, pp. 149-163.

World Bank (2002). Transition - The First Ten Years: Analysis and Lessons for Eastern Europe and the former Soviet Union. Washington, D.C. : World Bank. pp. 1-30.

Zahradil, Jan (2004). The Realism Instead of Illusions: The Blue Chance for the Czech Diplomacy (Realismus místo iluzí: Modrá šance pro českou diplomacii) 